\title{
An examination of peer aggression and victimization in relation to psycho-social variables"
}

\section{Arzu KURNAZ**}

\author{
Emine Gül KAPÇI ${ }^{* * *}$
}

\begin{abstract}
The present study aimed to identify the variables in relation to overt and relational aggression and victimization. The study group consisted of children $(n=384)$ attending 6th, 7th and 8th grades of elementary schools in Ankara. Children completed negative cognitive errors, aggression, victimization and perceived parenting scales while their parents filled in emotion regulation and behavior problems scales. A negative relationship was found between age and overt and relational aggresion. Regression analyses demonstrated that ADHD and social problems subscales, cognitive errors and perceived father attitudes predicted overt and relational aggression and victimization. Findings were discussed in relation to social-emotional variables and negative cognitions in our understanding of the aggression and victimization.
\end{abstract}

Keywords: Overt aggression, relational aggression, overt victimization, relational victimization, negative cognitive errors, emotion regulation.

\footnotetext{
* The present article is partly based on the MSc thesis of the first author.

** PhD student, Ankara University, Institute of Educational Sciences, Psychological Services in Education, Ankara, Turkey. E-mail: arzukurnaz@windowslive.com

${ }_{* * *}$ Prof. Dr., Ankara University, Faculty of Educational Sciences, Department of Psychological Services in Education, Ankara, Turkey. E-mail: kapci@ankara.edu.tr
} 


\section{SUMMARY}

Purpose and Significance: It is now widely accepted that children who exhibit peer aggression and those who are exposed to peer victimization are at risk for developing social-emotional problems. Research in general demonstrated that boys exhibit more aggression than girls and girls in turn are more exposed to peer victimization. However, it is stated that gender differences in aggression and victimization could stem from aggression and victimization type. In other words, girls are as aggressive as boys but they may exhibit more relational aggression, such as gossip and rejection rather than overt aggression such as hitting, yelling. The first aim of the present study is to examine gender differences in relation to overt and relational aggression and victimization. Second aim is to identify psycho-social variables that predict aggression and victimization among school age children.

Methods: A total of 384 children participated in the study (girls $\mathrm{n}=216$; $56 \%$ and boys $\mathrm{n}=168 ; 44 \%)$ with a mean age of $13(\mathrm{SD}=.85)$. The study group consisted of children living in Ankara and attending 6th, 7th and 8th grades of elementary schools. Children completed the Negative Cognitive Errors Questionnaire (NCEQ) Children's Self Experience Questionnaire-Self Report (CSEQ-SR) and Children's Social Behavior Scale-Self Report (CSBS-SR), EMBU-Mother and EMBU-Father form to assess negative cognitive errors, peer victimization, peer aggression and perceived mother and father attitutude respectively. Parents filled in Emotion Regulation Checklist (ERC) and The Revised Conners' Parent Rating Scale-Long Form (CPRS-R). According to parental report, children were from low income $(32 \%)$, middle income $(60 \%)$ and high income (8\%) families.

Results: Results demonstrated that there were no significant difference in mean overt and relational aggression scores among girls and boys. A negative relationship was found between age and overt and relational aggresion. A number of stepwise regression analyses were conducted. Analyses demonstrated that CPRS-R's Attention Deficiency and Hyperactivity subscale (ADHD) and NCEQ predicted relational aggression. CPRS-R's ADHD-subscale and Opposition and Perfectionizm predicted overt aggression. Overt victimization was predicted by the CPRS-R's Anxiety-Shyness-subscale and NCEQ. Relational victimization, on the other hand, was predicted by NCEQ, EMBU-Father form and CPRS-R's Social Problems-subscale.

Discussion and Conclusions: Findings highlights the importance of studying not only social-emotional variables, but also negative cognitions in studying peer aggression and victimization among school age children. Following studies investigating the presence, type and severity of negative cognitions may illuminate our understanding of peer aggression and victimization. 


\section{Akran Saldırganlığı ve Mağduriyetinin Psiko-Sosyal Değişkenler Açısından İncelenmesi*}

\section{$\operatorname{Arzu}$ KURNAZ ${ }^{* *}$}

\author{
Emine Gül KAPÇI***
}

ÖZ. Araştırmanın amacı, saldırganlık ve mağduriyetin gözlenen ve ilişkisel boyutlarını yordayan değişkenlerin belirlenmesidir. Ankara ilinde 6.-8. sinıflara devam eden 384 öğrenci araştırma grubunu oluşturmuştur. Öğrenciler olumsuz bilişsel hatalar, saldırganlık, mağduriyet ve algılanan anababa tutumu ölçeklerini, anababaları ise davranış sorunları ve duygu ayarlama ölçeklerini doldurmuşlardır. Öğrencinin yaşı ile gözlenen ve ilişkisel saldırganlık arasında negatif bir ilişki olduğu bulunmuştur. Regresyon analizleri, davranış sorunları ölçeğinin dikkat eksikliği hiperaktivite ve sosyal problemler gibi bazı alt ölçeklerinin, bilişsel hataların ve algılanan baba tutumunun gözlenen ve ilişkisel saldırganlık ile gözlenen ve ilişkisel mağduriyeti yordadığını göstermiştir. Bulgular, sosyal-duygusal değişkenlerle, olumsuz bilişsel hatalar gibi bilgi işleme süreçlerinin saldırganlık ve mağduriyetle ilişkisi bağlamında tartışılmıştır.

Anahtar Sözcükler: Gözlenen saldırganlık, ilişkisel saldırganlık, gözlenen mağduriyet, ilişkisel mağduriyet, olumsuz bilişsel hatalar, duygu ayarlama.

\footnotetext{
${ }^{*}$ Bu makale ilk yazarın yüksek lisans tezinden yararlanılarak hazırlanmıştır.

** Doktora öğrencisi, Ankara Üniversitesi Eğitim Bilimleri Enstitüsü Eğitimde Psikolojik Hizmetler Bölümü, Ankara, Türkiye. E-posta: arzukurnaz@windowslive.com

*** Prof. Dr., Ankara Üniversitesi Eğitim Bilimleri Fakültesi Eğitimde Psikolojik Hizmetler Bölümü. E-posta: kapci@ankara.edu.tr
} 


\section{GíRiş}

Akran saldırganlığı ve mağduriyeti uyum sorunlarının en güçlü yordayıcılarından biridir (Crick, 1996; Coie, Lochman, Terry ve Hyman, 1992; Storch, Masia-Warner, Crisp ve Klein, 2005). Çocukluk döneminde ortaya çıkan saldırganlığın akran reddi (Laird, Jordan, Dodge, Pettit ve Bates, 2001), mağduriyetin ise depresyonu (Storch, Phil, Nock, MasiaWarner ve Barlos, 2003), sosyal kaygiyı (Storch ve Masia-Warner, 2004), reddedilmeyi (Hannish ve Guera, 2002) ve davranış sorunlarını (Schwartz, McFadyen-Ketchum, Dodge, Pettit ve Bates, 1998) yordadığı bilinmektedir. Üstelik bu çocuklar uyum sorunlarının yanı sıra kimi gelişimsel yeterliliklerin kazanılması açısından da risk altında olabilir. Örneğin, araştırmacılar sosyal becerilerin kazanılmasında akran ilişkilerinin önemli olduğunu bulmuştur (Dodge, Schlundt, Schocken ve Delugach, 1983). Çocukluk dönemindeki saldırgan davranışları nedeniyle akranları tarafından reddedilen çocuklar, sosyal becerilerin kazanımı ile ilgili sorunlar yaşayabilirler. Çocuğun sosyal-duygusal gelişimi üzerindeki bu olumsuz etkileri nedeniyle saldırganlık ve mağduriyet ile ilişkili değişkenlerin açığa çıkarılması önemlidir.

\section{Akran Saldırganlığı ve Mağduriyeti: Cinsiyet ve Yaş}

$\mathrm{Bu}$ alanda yapılan çalışmalar saldırganlık ve mağduriyetin çocuğun cinsiyeti (Archer, 2004; Cheng, 2009; Crick ve Grotpeter, 1995), çocuğun yaş1 (Cillesen ve Mayeux, 2004; Giles ve Heyman, 2005; Ostrov ve Keating, 2004), çocuğun duygu ayarlaması (Cicchetti, Ackerman ve Izard, 1995; Shields ve Cicchetti, 1998) ve çocuğun çeşitli bilişsel özellikleri (Epkins, 2000; Leung ve Poon, 2001) ile ilişkili olduğuna işaret etmektedir.

Çocuğun cinsiyeti ile akran saldırganlığının gözlenen (örneğin vurma) ve ilişkisel boyutları (örneğin dışlama) arasındaki ilişkileri gözlem yoluyla inceleyen bir çalışmada gözlenen saldırganlığın erkekler, ilişkisel saldırganlığın ise kızlar arasında daha yaygın olduğu görülmüştür (Ostrov, Woods, Jansen, Casas ve Crick, 2004). Bu bulgulara paralel biçimde gözlenen mağduriyetin erkekler, ilişkisel mağduriyetin ise kızlar arasında daha yaygın olduğu bulunmuştur (Ostrov ve Keating, 2004; Paquette ve Underwood, 1999). Loeber ve Hay'in (1997) yaş ile akran saldırganlığ ve mağduriyeti arasındaki ilişkileri ele aldığ bir değerlendirme çalışmasında, genel olarak gözlenen saldırganlığın ve gözlenen mağduriyetin yaşla birlikte azaldığı, ilişkisel saldırganlığın ve ilişkisel mağduriyetin ise yaşla birlikte arttı̆̆ bildirilmişsir. 


\section{Akran Saldırganlığı ve Mağduriyeti: Duygu Ayarlama}

Akran saldırganlığı ve mağduriyeti ile ilişkili olduğu düşünülen diğer bir değişken de duygu ayarlamadır. Duygu ayarlama (emotion regulation), bireyin sosyal çevreye uyum sağlayabilmek ve amaçlarına ulaşabilmek için duygusal tepkilerini ayarlayabilmesidir. Duygular bireyin karşılaştı̆̆ 1 problemlere uyum sağlayıcı tepkiler vermesine yardımcı olmakta (Levenson, 1994), önemli olayların hatırlanmasında belleği güçlendirmekte (Phelps, 2006) ve kişilerarası ilişkilerde bireye rehberlik etmektedir (Matsumato, 2002). Ancak tüm bu sayılan yararlarına rağmen duygu ayarlamada kullanılan stratejiler sağlıklı olduğu sürece duygular bireyin uyumunu artırıcıdır. İşlevi bozan ya da yetersiz duygu ayarlama stratejileri ise bireyin sosyal-psikolojik uyumunu olumsuz biçimde etkileyebilmektedir. Hill, Degnan, Calkins ve Keane (2006), okulöncesi dönemde bulunan çocuklarda saldırganlık gibi dışayönelim sorunlarını boylamsal olarak değerlendirdikleri bir çalışmada, kız çocuklarında, duygu ayarlamanın dışayönelim sorunlarını yordadığını bulmuştur. Aynı çalışmada iki yaşında dışayönelim sorunları sergiledikleri halde yüksek düzeyde duygu ayarlama becerisi olan kız çocuklarının 4-5 yaşlarında sergiledikleri dışayönelim sorunlarının azaldığı görülmüştür. Erkek çocuklarında ise duygu ayarlama dışayönelim sorunlarını yordamamıştır. Başka bir boylamsal araştırmada da Rydell, Berlin ve Bohlin (2003), beş yaşındaki çocuklarda kızgınlık duygusunun dışayönelim sorunları ile ilişkili olduğunu, kızgınlık duygusunu ayarlayamamanın ise dışayönelim sorunlarını yordadığını bulmuştur. Aynı çalışmada neşe gibi olumlu duyguların uyum sağlamanın en güçlü yordayıcısı olduğu, duygulanım olumlu da olsa olumsuz da olsa duygu ayarlayamama dışayönelim sorunları ile ilişkili bulunmuştur. Duygu ayarlama becerisinin bir diğer yönü olumsuz duyguların yoğunluğu ve süresidir. Hem ana-baba hem de öğretmen değerlendirmesine dayalı bir başka boylamsal çalışma, olumsuz duyguları yoğun olan çocukların daha fazla davranış sorunları sergilediklerini bildirmiştir (Eisenberg, Fabes, Guthrie, Murphy, Maszk, Holmgren ve Suh, 1996).

\section{Akran Saldırganlığı ve Mağduriyeti: Bilişsel Hatalar}

Çocuğun saldırgan davranışlarının gelişiminde duygu ayarlama kadar bilişsel süreçler de etkili olabilir. Örneğin, Bandura, Barbaranelli, Caprara ve Pastorelli (1996), 10-15 yaşlarındaki 799 çocuğun katıldığı bir çalışmada, saldırgan davranışları nedeniyle sorumluluğu olmadığını düşünen, mağduru suçlayan, saldırganlığın sonuçlarını göz ardı eden çocukların saldırganlık düzeylerinin daha yüksek olduğunu bulmuşlardır. Bandura v.d.'nin (1996) bulguları ile tutarlı olarak, sosyal bilgi işleme süreci yaklaşımını temel alan 
araştırmalar, saldırgan davranışları sergileyen çocukların, saldırganlığın sonuçlarını olumlu değerlendirdiklerini ortaya koymuştur (Crick ve Dodge, 1996; Crick ve Werner, 1998; Lochman ve Dodge, 1994). Saldırgan davranışları bilgi işleme süreciyle açıklayan araştırmacılar, bilgi işleme süreçlerindeki niteliksel farklılıkların saldırgan davranışlara kaynaklık ettiğini bildirmektedir. Örneğin, saldırganlık gösteren çocukların çelişkili durumlarda sosyal ipuçlarını daha düşmanca algıladıkları (Crick ve Dodge, 1996; Dodge ve Coie, 1987), daha az sayıda etkili problem çözme stratejisi üretebildikleri (Asarnow ve Callon, 1985) ve daha düşmanca amaçlara sahip oldukları (Erdley ve Asher, 1996) bulunmuştur.

Saldırgan davranışlar ile bilişsel hatalar arasındaki ilişkilere dikkat çeken araştırma bulguları da bulunmaktadır. Örneğin, saldırgan davranışlar sergileyen çocukların sosyal etkileşimdeki diğer bireylerin niyetlerini (Rudolph ve Clark, 2001) ve saldırganlığın sonuçlarını (Schwartz v.d. 1998) çarpıtarak algıladıkları bulunmuştur. Özellikle saldırgan davranışlar nedeniyle suçluluk duygusunun olmaması (Bandura v.d. 1996) ve sosyal ipuçlarını düşmanca algılama eğilimi (Crick ve Dodge, 1996; Crick ve Werner, 1998; Lochman ve Dodge, 1994) saldırganlığın bilişsel hatalarla da ilişkili olabileceğine işaret etmektedir. Felaketleştirme, aşırı genelleme, kişiselleştirme ve seçici soyutlama daha çok depresyon ve kaygı bozukluklarıyla ilişkili bulunan bilişsel hatalardır (Leitenberg, Yost ve Carroll-Wilson, 1986).

\section{Akran Saldırganlığı ve Mağduriyeti: Ana-Baba Tutumları}

Saldırganlık ve mağduriyetin gelişimi, çocuğun duygu ayarlaması ya da olumsuz bilişsel hatalarının varlığ 1 gibi çeşitli bireysel özelliklerinin yanı sıra içinde bulunulan sosyal çevre ile de ilişkili olabilir. Belki de sosyal çevre içerisindeki en önemli öğe ailedir. Araştırmalar, fiziksel istismar (Burnette ve Reppucci, 2009) gibi patolojik durumların yanısıra kimi anababa tutumlarının çocuğun saldırgan davranışlarının gelişimine katkıda bulunabileceğini göstermiştir (Genç ve Aksu, 2010). Çeşitli kültürlerde yapılan araştırmalar, otoriter anababa tutumu ile çocuğun saldırgan davranışları arasında ilişki olduğunu bulmuştur (Balkaya ve Ceyhan, 2007; Bayer ve Cegala, 1992). İzin verici anababa tutumunun da çocuğun saldırganlığı ile ilişkili olabileceği düşünülmektedir. Örneğin, Sandstrom (2007) tarafından yapılan bir araştırmada 9-11 yaşlarındaki çocuklarda, annenin izin vericiliği ile çocuğun ilişkisel saldırgan davranışları arasında ilişki olduğu görülmüştür. Joussemet v.d. de (2008), anaokulu döneminde bulunan çocuklarla yürüttükleri çalışmalarında, anneleri daha kontrolcü olan çocukların ilerleyen okul yılları boyunca gözlenen saldırganlığın ortaya 
çıkması açısından risk altında olduklarını açığa çıkarmıştır. Bu riskin çocuğun cinsiyetinden, annenin genç olmasından ve anababanın ayrı olmasından bağımsız olması dikkat çekicidir. Başka bir çalışmada da Alink v.d. (2008), annenin kullandığı olumsuz disiplin yöntemleri ile saldırganlık arasındaki ilişkide annenin duyarlılığının aracı (moderator) değişken olduğunu, bir diğer deyişle, anne duyarsız olduğunda olumsuz disiplin yöntemlerinin çocuğun saldırgan davranışlar sergilemesine katkıda bulunduğunu göstermiştir. Sonuç olarak çocuğun sergilediği saldırgan davranışlar anababanın tutumu ve anababa-çocuklar arasındaki ilişkilerin niteliği ile ilişkili olabilir.

\section{Araștırmanın Amacı}

Türkiye'de, özellikle 2000'li yıllardan itibaren çocuk ve ergenlerin sergilediği saldırganlık ile ilgili araştırmalarda bir artış gözlenmektedir. Türkiye'de gerçekleştirilen bu araştırmaların her biri önemli bilgiler vermekle birlikte, saldırgan davranışı yordayan etmenlerin ele alındığ 1 araştırmalar oldukça sınırlıdır. Örneğin, duygu ayarlama gibi saldırganlık ile bağlantılı olabilecek etmenler henüz çalışılmamıştır. Ayrıca, hem Türkiye'de hem de yurt dışı alanyazında saldırganlıkla ilgili çok sayıda araştırma yapılmış olmasına karşın saldırganlığın mağdurlarına ilişkin araştırmalar da sınırlıdır. Çocuğun sosyal-duygusal gelişiminde oldukça önemli olan saldırganlık ve mağduriyet ile ilişkili olabilecek etmenlerin incelenmesi bu araștırmanın temel konusudur.

Yaş ve cinsiyet gibi demografik değişkenlerin yanı sıra, duygu ayarlama, ana-baba tutumları ve bilişsel hataların birarada ele alındığı bir araştırma akran saldırganlığı ve mağduriyetini anlama ve olası çözüm önerilerini geliştirme konusunda hem araştırmacılara hem de uygulamacılara önemli bilgiler sağlayabilir. Sonuç olarak bu araştırmanın genel amacı yukarıda belirtilen değişkenlerle akran saldırganlığı ve mağduriyeti arasındaki ilişkilerin incelenmesidir. Bu genel amaç doğrultusunda aşağıda belirtilen araştırma sorularının yanıtları aranacaktır:

1. Çocuğun yaşı ile gözlenen saldırganlık, ilişkisel saldırganlık, gözlenen mağduriyet ve ilişkisel mağduriyet arasında ilişki var mıdır?

2. Çocuğun cinsiyetine, anababanın eğitim düzeyine ve ailenin gelir grubuna göre gözlenen ve ilişkisel saldırganlık düzeyi farklılaşmakta mıdır?

3. Çocuğun cinsiyetine, anababanın eğitim düzeyine ve ailenin gelir grubuna göre gözlenen ve ilişkisel mağduriyet düzeyi farklılaşmakta mıdır?

4. Duygu ayarlama, bilişsel hatalar, algılanan ana-baba tutumu ve duygusal davranışsal problemler gözlenen ve ilişkisel saldırganlık ile gözlenen ve ilişkisel mağduriyeti yordamakta mıdır? 


\section{YÖNTEM}

\section{Araştırma Modeli}

$\mathrm{Bu}$ araştırma ilişkisel tarama modeline dayanarak gerçekleştirilmiştir. İlişkisel tarama modellerinin özelliği varolan değişkenler arasındaki ilişki değerlendirilerek çıkarımlarda bulunulmasıdır.

\section{Katılımcilar}

$\mathrm{Bu}$ çalışmanın araştırma grubunu, Ankara'nın alt, orta ve üst sosyoekonomik düzeyi temsil ettiği düşünülen semtlerinde bulunan ilköğretim okullarının 6., 7. ve 8. sınıflarına devam eden çocuklar oluşturmaktadır. Çalışmaya, $12-15$ yaş aralığında ve yaş ortalaması $\bar{x}=13(\mathrm{SS}=.85)$ olan toplam 384 çocuk katılmıştır. Bu çocukların \%56'sı kız $(n=216), \% 44$ 'ü erkektir $(\mathrm{n}=168)$. Çocuklara ilişkin değerlendirme yapan ebeveynlerin \%71'ini anneler $(\mathrm{n}=273), \% 29$ 'unu ise babalar $(\mathrm{n}=111)$ oluşturmuştur. Çalışmaya katılan çocukların aileleri, aylık gelir düzeylerine göre gruplandırıldı ̆̆ında \%32'sinin alt (100.00-999.00 TL), \%60'ının orta (1000.00-2999.00 TL) ve \%8'inin üst (3000.00-8000.00 TL) gelir grubunda yer aldığı görülmüştür.

\section{Veri Toplama Araçları}

Çocuk ve Ana-Baba Bilgi Formu: Çocuklar tarafindan doldurulan bilgi formunda yaş, cinsiyet ve sınıf düzeyine ilişkin bilgiler yer almaktadır. Anababalar tarafindan doldurulan bilgi formunda yanıtlayıcının anne ya da baba olma durumu, yaşı, medeni durumu, ailenin aylık ortalama geliri, çocuk sayısı ve çalışma durumuna ilişkin bilgiler yer almaktadır.

Çocuk Sosyal Davranış Ölçeği-Kişisel Bildirim (ÇSDÖ-KB). Crick ve Grotpeter (1995) tarafindan geliştirilen Çocuk Sosyal Davranış ÖlçeğiKişisel Bildirim (Children's Social Behavior Scale-Self Report) çocukların sergilediği gözlenen saldırganlık ve ilişkisel saldırganlık düzeylerini değerlendirmektedir. ÇSDÖ-KB toplam 15 maddeden ve beş boyuttan oluşmaktadır. $\mathrm{Bu}$ boyutlar, ilişkisel saldırganlık, gözlenen saldırganlı, özgeci (prosocial) davranış, dahilolma ve yalnızlıktır. Ölçekte her bir madde için olası yanıtlar "1'den (Hiçbir zaman)" "5'e (Her zaman)" kadar değerlendirilmektedir. ÇSDÖ-KB, ölçekten alınan puanın yüksekliği saldırganlık düzeyinin yüksekliğine işaret edecek biçimde puanlanmaktadır. $\mathrm{Bu}$ nedenle özgeci davranış1 değerlendiren 3., 6., 7. ve 14 . maddeler ters kodlanmaktadır. Ölçeğin psikometrik değerlerine ilişkin veriler sınırlıdır. Bununla birlikte boyutlar için Cronbach Alpha değerleri, gözlenen 
saldırganlık .94, ilişkisel saldırganlık .83, özgeci davranış .91, dahil olma .90 ve yalnızlık .92 olarak hesaplamıştır.

Ölçeğin Türk örneklemine uyarlama çalışması Kapçı ve Kurnaz (2009) tarafindan yapılmıştır. Ankara'da üç farklı sosyoekonomik düzeyi temsil ettiği düşünülen ilköğretim okullarının 6.(n=65), 7.(n=241), ve 8.(n=109) sınıflarına devam eden toplam 415 öğrencinin $(k 1 z n=205$; erkek $n=210)$ katıldığı araştırmadan elde edilen verilerle doğrulayıcı faktör analizi (DFA) yapılmıştır. DFA, modellerin uyum indeksleri ve Ki-kare değerleri incelenmiştir. DFA analizleri önerilen modelin uygunluğunu desteklemiştir $(G F I \geq .94, A G F I \geq .92, R M S R \leq .04$, RMSEA $\leq .043)$. ÇSDÖ-KB ile Olweus Zorba/Mağdur Ölçeğì"nin Zorba Formu (Olweus, 1996; Uyarlayan, Dölek, 2002) arasındaki korelasyon $(r=.47, p<.01)$ ölçeğin ölçüt geçerliğini destekler niteliktedir. Test-tekrar test kararlılığ $(\mathrm{r}=.64, \mathrm{p}<.01)$ ve iç tutarlık $(\alpha=.84)$ analizleri de ölçeğin güvenilirliğini desteklemiştir.

Bu çalışmadan elde edilen verilerle yapılan analizlerde Cronbach Alpha ile değerlendirilen iç tutarlık değerleri Gözlenen Saldırganlık için.74, İlişkisel Saldırganlık için .70 olarak hesaplanmıştır. Ayrıca bu çalışmada ölçeğin doğrulayıcı faktör analizi ile faktör yapısı test edilmiştir. $\mathrm{Bu}$ bağlamda elde edilen uyum indeksleri $\chi^{2} / \mathrm{Sd}=2.04$, RMSEA $=.05$, NNFI= $.96, \mathrm{CFI}=.97, \mathrm{NFI}=.94$ ve $\mathrm{AGFI}=.92$ olarak hesaplanmıştır. Bulgular ÇSDÖ-KB'nin güvenilir ve geçerli bir ölçek olduğuna işaret etmektedir. Bu çalışmada ölçeğin İlişkisel Saldırganlık ve Gözlenen Saldırganlık altboyutlarından yararlanılmışır. Herbir boyuttan alınan puanın yüksekliği o boyutta yer alan saldırgan davranıştaki artışa işaret etmektedir.

Çocuğun Bireysel Yaşantıları Ölçeği-Kişisel Bildirim (ÇBYÖ-KB). Crick ve Grotpeter (1996) tarafından, akran mağduriyetinin gözlenen ve ilişkisel boyutlarını değerlendirmek için geliştirilen Çocuğun Bireysel Yaşantıları Ölçeği- Kişisel Bildirim (Children's Self Experience Questionnaire-Self Report) toplam 15 maddeden oluşmaktadır. ÇBYÖ-KB ilişkisel mağduriyet, gözlenen mağduriyet ve özgeci (prosocial) davranış olmak üzere üç boyuttan oluşmaktadır. Her bir madde için olası yanttlar "1'den (Hiçbir zaman)" "5'e (Her zaman)"a kadar sınıflandırılmaktadır. İlişkisel mağduriyet ve gözlenen mağduriyet boyutlarından alınabilecek en düşük puan 5 , en yüksek puan ise $25^{\prime}$ tir. Ölçekten alınan puanın yüksekliği mağduriyet düzeyinin yüksekliğini göstermektedir. $\mathrm{Bu}$ nedenle özgeci davranış alt-ölçeğinde yer alan 1., 5., 8., 12. ve 15. maddeler ters kodlanmaktadır. Açımlayıcı faktör analizi, toplam varyansın \%50.5'ini açıklayan üç boyutlu bir yap1 önermiş̧tir İlişkisel mağduriyet boyutu varyansin \%34.9'unu, gözlenen mağduriyet boyutu varyansin \%15.6'sin1 ve özgeci davranış boyutu ise varyansın \%8.2'sini açıklamıştır. Cronbach Alpha değerleri, gözlenen mağduriyet boyutu için .78, ilişkisel mağduriyet 
boyutu için .80 ve özgeci davranış boyutu için .77 olarak hesaplanmıştır (Crick ve Grotpeter 1996).

Ölçeğin Türk örneklemine uyarlama çalışması Kurnaz ve Kapçı (2009) tarafından gerçekleştirilmiştir. İlköğretim okullarının 6. $(\mathrm{n}=139)$, 7.( $\mathrm{n}=165)$ ve 8. $(n=118)$ sinıflarına devam eden toplam 422 öğrencinin ( $k 1 z \quad n=207$; erkek $n=215$ ) katıldığı uyarlama çalışmasının doğrulayıcı (DFA) faktör analizi sonuçları, Crick ve Grotpeter (1996) tarafindan önerilen "ilişkisel mağduriyet", "gözlenen mağduriyet" ve "özgeci davranış" olarak adlandırılan üç boyutlu yapının desteklendiğini göstermiştir $(G F I \geq .90$; $A G F I \geq .87 ; \quad R M S R \quad \leq .053 ;$ RMSEA $\leq .063)$. Cronbach Alfa ile değerlendirilen iç-tutarlık güvenirliği $(\alpha=.80)$ ve test-tekrar test kararlılığ $(\mathrm{r}=.90, \mathrm{p}<.01)$ ölçeğin güvenirliğini desteklemektedir. ÇBYÖ-KB ile Olweus Zorba/Mağdur Ölçeği”nin Mağdur Formu (Olweus, 1996; Uyarlayan, Dölek, 2002) arasındaki korelasyon $(\mathrm{r}=.70, \mathrm{p}<.01)$ ölçeğin ölçüt geçerliğini destekler niteliktedir.

$\mathrm{Bu}$ çalışmadan elde edilen verilerle yapılan analizlerde Cronbach Alpha değerleri Gözlenen Mağduriyet için .67 ve İlişkisel Mağduriyet için .60 olarak hesaplanmıştır. Ayrıca bu çalışmada ölçeğin doğrulayıcı faktör analizi ile faktör yapısı test edilmiştir. Bu bağlamda elde edilen uyum indeksleri $\chi^{2} / \mathrm{Sd}=3.12, \mathrm{RMSEA}=.08, \mathrm{NNFI}=.86, \mathrm{CFI}=.89, \mathrm{NFI}=.84$ ve $\mathrm{AGFI}=.87$ olarak hesaplanmıştır. $\mathrm{Bu}$ çalışmada ölçeğin İlişkisel Mağduriyet ve Gözlenen Mağduriyet alt-boyutlarından yararlanılmıştır.

Olumsuz Bilişsel Hatalar Ölçeği (OBHÖ; Negative Cognitive Errors Questionnaire). Leitenberg, Yost ve Caroll-Wilson (1986) tarafindan çocukların olumsuz bilişsel hatalarını değerlendirmek amacıyla geliştirilmiştir. Dört alt-ölçekten oluşan OBHÖ'de 24 madde yer almaktadır. OBHÖ'nün alt-ölçekleri, felaketleştirme, aşırı genelleme, kişiselleştirme ve seçici soyutlamadır. Her bir alt-ölçek 6 madde içermektedir. Ölçek, "1 (Tamamen Aynı Düşünürüm)" - "5 (Hiç Böyle Düşünmem)" biçiminde 5'li derecelendirme ile değerlendirilmektedir. Ölçekten alınabilecek en düşük puan 24 , en yüksek puan 120 'dir. Ölçekten alınan puanın yüksekliği, olumsuz bilişsel hataların düşüklügüne işaret etmektedir.

Ölçeğin özgün formunda, alt-ölçekler için hesaplanan Cronbach Alpha değerlerinin .75-.82 arasında değiştiği görülmüsştür. Test tekrar test kararlılığı ise kabul edilebilir bir düzeydedir $(r=.65 ; \mathrm{p}<.01)$. Ölçeğin Türk örneklemine uyarlama çalışması Aydın (2006) tarafından yapılmıştır. Soyutlama, felaketleştirme, kişiselleştirme ve aşırı genelleme alt-ölçeklerinin iç-tutarlıkları sırasıyla .66, .73, .74 ve .77 olarak bulunmuştur. Ölçeğin toplam puanı için Cronbach alpha katsayısı .91 ve iki yarım test güvenirliği .87 olarak hesaplanmıştır. 
$\mathrm{Bu}$ çalışmadan elde edilen verilerle yapılan analizlerde, Cronbach Alpha değerleri Felaketleştirme için .66, Kişiselleştirme için .63, Seçici Soyutlama için .60 ve Aşırı Genelleme için .71 olarak bulunmuştur. Ölçeğin tamamı için hesaplanan Cronbach Alpha değeri .87'dir. Ayrıca bu çalışmada ölçeğin doğrulayıcı faktör analizi ile faktör yapısı test edilmiştir. Elde edilen uyum indeksleri $\chi^{2} / \mathrm{Sd}=2,52, \mathrm{RMSEA}=.06, \mathrm{NNFI}=.94, \mathrm{CFI}=.95, \mathrm{NFI}=$ .91 ve $\mathrm{AGFI}=.85$ olarak hesaplanmıştır.

Algilanan Anne Tutumu-Kisa Form (AAT-KF) ve Algilanan Baba Tutumu-Kısa Form (ABT-KF). Çocukların anne ve babalarının kendilerine yönelik davranış biçimlerine ilişkin algılarını değerlendiren bu ölçek Arrindell v.d. (1999; Egna Minnen Betraffonde Uppfostron -My Memories of Upbringing-) tarafindan geliştirilmiştir. Her biri 29 maddeden oluşan ölçekler anne ve baba için ayrı ayrı doldurulmaktadır. Toplam 81 maddeden oluşan özgün ölçekler İsveçli araştırmacılar Perris, Jacobsson, Lindström, von Knorring ve Perris (1980) tarafından geliştirilmiştir. Özgün ölçek, Duygusal Yakınlık, Reddetme ve Aşırı Koruma olmak üzere üç boyuttan oluşmaktadır. 23 maddeden oluşan kısa formlar ise Arindell v.d. (1999) tarafından uyarlanmıştır. Arindell v.d. (1999), kısa formun Cronbach Alpha değerini .72 olarak hesaplamıştır. Bir başka çalışmada reddetme, aşırı koruma ve duygusal yakınlık boyutlarının Cronbach Alpha değerleri sirasiyla $.89, .79$ ve .90 olarak bulunmuştur (Irons, Gilbert, Baldwin, Baccus ve Palmer, 2006).

Ölçeklerin kısa formlarının Türk çocuklarına uyarlama çalışması Sümer ve Engin tarafından 2004 yılında yapılmıştır. Uyarlama çalışması sırasında ölçeğe Karşıllaştırma boyutu eklenmiştir. AAT-KF ve ABT-KF ölçeklerine verilen yanıtlar "1 (Hiçbir zaman)"-"6 (Her zaman)" biçiminde değerlendirilmektedir. Ölçekten alınan puanın yüksekliği anne ve babaya ilişkin olumsuz algının yüksekliğine işaret etmektedir.

$\mathrm{Bu}$ çalışmadan elde edilen verilerle gerçekleştirilen analizler Cronbach Alpha değerlerinin Duygusal Yakınlık için .83, Reddetme için .77, Aşırı Koruma için .65 ve Karşılaştırma için .71 olduğunu göstermiştir. Ölçeğin tamamı için hesaplanan Cronbach Alpha değeri .76'dır. Ayrıca bu çalışmada ölçeğin doğrulayıcı faktör analizi ile faktör yapısı test edilmiştir. Elde edilen uyum indeksleri $\chi^{2} / \mathrm{Sd}=2.58, \mathrm{RMSEA}=.06, \mathrm{NNFI}=.91, \mathrm{CFI}=.92, \mathrm{NFI}=$ .88 ve AGFI $=.83$ olarak hesaplanmıştır. Bulgular AAT-KF'nin güvenilir ve geçerli bir ölçek olduğunu göstermiştir.

$\mathrm{Bu}$ çalışma da ABT-KF'nin de güvenirlik ve geçerlik analizleri yapılmıştır. Güvenirlik analizlerinde ölçeğin boyutları Duygusal Yakınlık için .85, Reddetme için .79, Aşırı Koruma için .67 ve Karş1laştırma için .73 Cronbach Alpha değerleri elde edilmiştir. Ölçeğin tamamı için hesaplanan Cronbach Alpha değeri ise .82 'dir. Ölçeğin faktör yapısı doğrulayıcı faktör 
analizi ile test edilmiştir. Bu bağlamda elde edilen uyum indeksleri $\chi^{2} / \mathrm{Sd}=$ 2.31, $\mathrm{RMSEA}=.06, \mathrm{NNFI}=.93, \mathrm{CFI}=.90, \mathrm{NFI}=.89$ ve $\mathrm{AGFI}=.85$ olarak hesaplanmıştır.

Duygu Ayarlama Ölçeği (DAÖ). Shields ve Cicchetti (1997) tarafından geliştirilen Duygu Ayarlama Ölçeği (Emotion Regulation Checklist), çocuğun duygu ayarlaması hakkında bilgi vermektedir. 24 maddeden oluşan DAÖ hem anababa hem de çocuğu tanıyan diğer bir yetişkin tarafindan doldurulabilen bir ölçektir. Ölçekte yer alan maddeler "1 (Hiçbir zaman)" ile "4 (Hemen her zaman)" arasında değişen değerler almaktadır. Ölçekten alınan toplam puanın yüksekliği çocuğun duygu ayarlamasının düşüklüğünü göstermektedir.

Shields ve Cicchetti (1997) ölçeğin, Değişkenlik/Olumsuzluk ve Duygu Ayarlama olmak üzere iki boyutlu bir yapıya sahip olduğunu göstermiştir. Ölçeğin özgün formunda, Cronbach Alfa ile değerlendirilen iç-tutarlık güvenirliği $(\alpha=.69)$ olarak hesaplanmıştır.

Ölçeğin Türk çocuklarına uyarlama çalışması Kapçı, Uslu, Akgün ve Acer (2009) tarafindan yapılmıştır. Doğrulayıcı faktör analizi önerilen iki boyutlu yapının Türk çocuklarına uygunluğunu desteklemektedir $(G F I \geq$ $0.86 ; A G F I \geq 0.83 ; R M S R \leq 0.04 ;$ RMSEA $\leq 0.06)$. Değerlendiriciler aras1 güvenirlik $(\mathrm{r}=.81)$, test-tekrar test kararlılığ $(\mathrm{r}=.90)$ ve iç tutarlık $(\alpha=.84)$ analizleri ile ölçeğin genel olarak yüksek bir güvenirlikle değerlendirme yaptığı bulunmuştur.

$\mathrm{Bu}$ çalışmadan elde edilen verilerle yapılan analizlerde Cronbach Alpha değeri .75 olarak hesaplanmıştır. Ayrıca bu çalışmada ölçeğin doğrulayıcı faktör analizi ile faktör yapısı test edilmiştir. Elde edilen uyum indeksleri $\chi^{2} / \mathrm{Sd}=1.74$, $\mathrm{RMSEA}=. .05, \mathrm{NNFI}=.81, \mathrm{CFI}=.83, \mathrm{NFI}=.68$ ve AGFI $=.87$ olarak hesaplanmıştır.

Yenilenmiş Conners Ana-Baba Dereceleme Ölçeği-Uzun Formu (YCADÖ-UF). Conners (2000) tarafından geliştirilen Yenilenmiş Conners Anababa Dereceleme Ölçeği-Uzun Formu (The Revised Conners' Parent Rating Scale-Long Form) anababalardan elde edilen veriler doğrultusunda 317 yaş aralığındaki çocuk ve ergenlerin duygusal ve davranışsal problemlerini değerlendirmektedir. Ölçeğin yanıtlanması ' 0 'dan (Hiç doğru değil)" "3'e (Çok doğru)" kadar, 4'lü derecelendirme biçiminde yapılmaktadır. Bu çalışmada, ölçeğin Conners Global İndeks-Toplam ve DSM-IV Semptomları Alt Ölçeği-Toplam dışındaki boyutları kullanılmıştır.

YCADÖ-UF toplam 80 maddeden ve 14 boyuttan oluşmaktadır. YCADÖ-UF'nin boyutları Karşı Gelme, Bilişsel Problemler/Dikkatsizlik, Hiperaktivite, Kaygı-Utangaçlık, Mükemmelliyetçilik, Sosyal Problemler, Psikosomatik, DEHB Indeksi, Conners Global Indeks-HuzursuzlukImpulsivite, Conners Global İndeks-Duygusal Değişkenlik, Conners Global 
Indeks-Toplam, DSM-IV Semptomları Alt Ölçeği-Dikkatsizlik, DSM-IV Semptomları Alt Ölçeği-Hiperaktivite-Dürtüsellik ve DSM-IV Semptomları Alt Ölçeği-Toplam olarak adlandırılmıştır.

Ölçeğin özgün formu ile yapılan analizler, boyutların Çocuklar için Depresyon Ölçeği (Kovacs, 1992) ile korelasyonlarının .23-.82 arasında olduğunu göstermiştir. Ölçeğin uzun ve kısa formları arasındaki ilişki ise .96-.98 olarak saptanmıştır. DEHB olan ve olmayan çocukların karşılaştırılmasında ölçeğin uzun formunun ayırt edici geçerliğe sahip olduğu görülmüsşür. Ölçekten elde edilen ham puanlar standart puanlara (tpuanları) dönüştürülmekte ve bireysel puanları değerlendirmede yüzdelik normlardan yararlanılmaktadır.

Ölçeğin Türk örneklemine uyarlama çalışması Kaner, Büyüköztürk, İşeri, Ak ve Özaydın (2006) tarafindan yapılmıştır. YCADÖ-UF'nin yapı geçerliği, doğrulayıcı faktör analizi (DFA) ile incelenmiştir. DFA ile hesaplanan uyum istatistikleri, ölçeğin özgün formunda yer alan modelin Türk kültürü için uygun olduğunu göstermektedir (RMSEA=.04; RMR=.04; $\mathrm{GFI}=.90 ; \mathrm{AGFI}=.89$ ).

$\mathrm{Bu}$ çalışmadan elde edilen verilerle yapılan güvenirlik analizlerinde YCADÖ-UF'nün boyutları için hesaplanan Cronbach Alpha değerlerinin .78 ile .91 arasında değiştiği görülmüştür. Ayrıca bu çalışmada ölçeğin doğrulayıcı faktör analizi ile faktör yapısı test edilmiştir. Elde edilen uyum indeksleri $\chi^{2} / \mathrm{Sd}=2.49$, $\mathrm{RMSEA}=.06, \mathrm{NNFI}=.95, \mathrm{CFI}=.91, \mathrm{NFI}=.93$ ve $\mathrm{AGFI}=.72$ olarak hesaplanmıştır.

\section{İşlem}

Araştırmanın katılımcılarına Ankara ili sınırlarındaki ilköğretim okullarından ulaşılmıştır. Toplam sekiz okuldan veriler toplanmıştır. Her okuldan iki sınıf seçilmiştir. Okul yönetimi bilgilendirilip gerekli izinler alındıktan sonra yönetimce uygun görülen bir derste, birinci araştırmacı öğrencilere araştırmanın amacını kısaca özetlenmiştir. Ardından gönüllü öğrenciler ve onların anababaları ölçekleri doldurmuşlardır. Araştırmaya katılmayı kabul etmeyen herhangi bir öğrenci olmamıştır.

$\mathrm{Bu}$ ölçeklerden kimisi çocuklar kimisi de anababaları tarafından doldurulmuştur. Çocuklar tarafından doldurulan ölçekler; Çocuk Sosyal Davranış Ölçeği-Kişisel Bildirim, Çocuğun Bireysel Yaşantıları ÖlçeğiKişisel Bildirim, Olumsuz Bilişsel Hatalar Ölçeği, Algılanan Anne Tutumu Ölçeği ve Algılanan Baba Tutumu Ölçeği'dir. Anababalar tarafından doldurulan ölçekler; Duygu Ayarlama Ölçeği, Yenilenmiş Conners Ebeveyn Derecelendirme Ölçeği-Uzun Formdur. 


\section{BULGULAR}

Çocuğun yaşı ile gözlenen ve ilişkisel saldırganlık ile gözlenen ve ilişkisel mağduriyet arasında iliş̧ki: Çocuğun yaşı ile gözlenen saldırganlık ve ilişkisel saldırganlık arasındaki ilişkiyi değerlendirmek için korelasyon analizleri yapılmıştır. Çocuğun yaşı ile ilişkisel saldırganlık $(r=-.15 ; \mathrm{p}<.05)$ ve gözlenen saldırganlık $(\mathrm{r}=-.21 ; \mathrm{p}<.01)$ arasında negatif yönde anlamlı bir ilişki bulunurken, çocuğun yaşı ile ilişkisel $(r=-.10 ; p=.14)$ ve gözlenen $(\mathrm{r}=.05 ; \mathrm{p}=.49)$ mağduriyet arasında anlamlı bir ilişki bulunmamıştır.

Çocuğun cinsiyetine, anababanın ĕgitim düzeyine ve ailenin gelir grubuna göre gözlenen ve ilişkisel saldırganlık düzeyinin değerlendirilmesi: Çocuğun cinsiyetine, anababanın eğitim düzeyine ve ailenin gelir grubuna göre gözlenen ve ilişkisel saldırganlık düzeyinin farklılaşıp farklılaşmadığını sınamak üzere çok değişkenli varyans analizi yapılmıştır. Çocuğun yaşı ile ilişkisel saldırganlık ve gözlenen saldırganlık arasında anlamlı bir ilişki bulunduğundan bu analizde yaş kovaryans olarak alınmıştır (MANCOVA). Çocuğun cinsiyeti, anababanın eğitim düzeyi ve ailenin gelir grubu bağımsız değişken, gözlenen ve ilişkisel saldırganlık toplam puanları bağımlı değişken, yaş ise kovaryans olarak analize dahil edilmişlerdir. Gözlenen ve ilişkisel saldırganlık düzeylerinde, yaş kovaryans olarak alındığında ele alınan değişkenlerin anlamlı bir farklılığa kaynaklık etmedikleri görülmüştür. Etki büyüklüklerini değerlendirmek amacıyla kısmi eta kare katsayısından $\left(\square^{2}\right)$ yararlanılmıştır (Cinsiyet $F=1.84 ; p>.05, \eta^{2}=$ .01; Anababa Eğitim $\mathrm{F}=.78 ; \mathrm{p}>.05 \eta^{2}=.01$; Ailenin Gelir Grubu $\mathrm{F}=1.75$; $\mathrm{p}>.05 \eta^{2}=.01 ;$ ).

Çocuğun cinsiyetine, anababanin ĕgitim düzeyine ve ailenin gelir grubuna göre gözlenen ve ilişkisel mağduriyet düzeyinin değerlendirilmesi: Benzer biçimde, çocuğun cinsiyetine, anababanın eğitim düzeyine ve ailenin gelir grubuna göre gözlenen ve ilişkisel mağduriyet düzeyinin farklılaşıp farklılaşmadığını sınamak üzere çok değişkenli varyans analizinden yararlanılmıştır (MANOVA). Çocuğun cinsiyeti, anababanın eğitim düzeyi ve ailenin gelir grubu bağımsız değişken, gözlenen ve ilişkisel mağduriyet toplam puanları ise bağımlı değişken olarak analize dahil edilmişlerdir. Gözlenen ve ilişkisel mağduriyet düzeylerinde, çocuğun cinsiyetinin, anababanın eğitim düzeyinin ve ailenin gelir grubunun anlamlı bir farkl111ğa kaynaklık etmedikleri görülmüştür (Cinsiyet $\mathrm{F}=.93 ; \mathrm{p}>.05 \quad \eta^{2}=. \mathbf{0 1}$; Anababa Eğitim F=.31; $>$ >.05 $\eta^{2}=.01 ;$ Ailenin Gelir Grubu F=.73; $>$ >.05 $\eta^{2}=.01 ;$ ).

Gözlenen ve ilişkisel saldırganlık ile gözlenen ve ilişkisel mağduriyeti yordayan değişkenlerin değerlendirilmesi: Gözlenen ve ilişkisel saldırganlık ile gözlenen ve ilişkisel mağduriyeti yordayan değişkenleri belirlemek 
amacıyla adımsal regresyon analizleri (stepwise) gerçekleştirilmiştir. Regresyon eşitliğine duygu ayarlama, olumsuz bilişsel hatalar, algılanan anne tutumu, algilanan baba tutumu ve duygusal davranışsal problemler değişkenleri girilmiştir. Gözlenen saldırganlığı yordayan değişkenleri belirlemek amacıyla yapılan adımsal regresyon analizinin bulguları Tablo $l$ 'de verilmiştir.

Tablo 1. Gözlenen saldırganlığı yordayan değişkenleri belirlemek üzere yapılanadımsal regresyon analizi'nin sonuçları

\begin{tabular}{lllllllll}
\hline Model & B & SH & Beta & $\mathbf{t}$ & $\mathbf{p}$ & $\mathbf{R}$ & $\mathbf{R}^{2}$ \\
\hline \multirow{2}{*}{$\mathbf{1}$} & (Değişken) & 4.29 & .14 & & 29.75 & .00 & \multirow{2}{*}{.37} & .14 \\
& DEHB İndeksi & .14 & .02 & .37 & 7.36 & .00 &. & \\
& (Değişken) & 4.23 & .14 & & 29.46 & .00 & & \\
$\mathbf{2}$ & DEHB İndeksi & .09 & .03 & .22 & 3.15 & .00 & .39 & .15 \\
& Karşı Gelme & .09 & .03 & .20 & 2.76 & .01 & & \\
& (Değişken) & 4.46 & .19 & & 23.99 & .00 & & \\
& DEHB İndeksi & .08 & .03 & .21 & 2.90 & .00 & & \\
$\mathbf{3}$ & Karş1 Gelme & .11 & .03 & .26 & 3.33 & .00 & .40 & .16 \\
& Mükemmeliyetçilik & -.06 & .03 & -.11 & -2.00 & .04 & & \\
\hline
\end{tabular}

Analiz sonucunda üç farklı model ortaya çıkmıştır. Üçüncü modelde $Y C A D \ddot{O}-U F$ 'nin DEHB İndeksi $(\beta=.24 ; \mathrm{t}=3.39 ; \mathrm{p}<.01)$, Karşı Gelme $(\beta=$ $.30 ; \mathrm{t}=3.41 ; \mathrm{p}<.01)$ ve Mükemmeliyetçilik $(\beta=-.16 ; \mathrm{t}=-2.04 ; \mathrm{p}<.05)$ boyutları gözlenen saldırganlığı yordamaktadır. YCADÖ-UF'nin DEHB Indeksi tek başına gözlenen saldırganlığın \%14'ünü yordarken $\left(\mathrm{R}=.37 ; \mathrm{R}^{2}=\right.$ .14), YCADÖ-UF'nin Karş1 Gelme boyutu ile birlikte gözlenen saldırganlığın \%15'ini yordamıştır $\left(\mathrm{R}=.39 ; \mathrm{R}^{2}=.15\right)$. YCADÖ-UF'nin DEHB İndeksi, Karşı Gelme ve Mükemmeliyetçilik boyutları birlikte gözlenen saldırganlığın \%16'sını yordamıştır $\left(\mathrm{R}=.40 ; \mathrm{R}^{2}=.16\right)$.

İlişkisel saldırganlığı yordayan değişkenleri belirlemek amacıyla yapılan adımsal regresyon analizinin (stepwise) bulguları Tablo 2'de verilmiştir.

Tablo 2. İlişkisel saldırganlığı yordayan değişkenleri belirlemek üzere yapılan adımsal regresyon analizi'nin sonuçları

\begin{tabular}{|c|c|c|c|c|c|c|c|c|}
\hline \multicolumn{2}{|c|}{ Model } & \multirow{2}{*}{$\frac{\text { B }}{11.04}$} & \multirow{2}{*}{$\begin{array}{c}\text { SH } \\
.90\end{array}$} & \multirow[t]{2}{*}{ Beta } & \multirow{2}{*}{$\frac{\mathbf{t}}{12.28}$} & \multirow{2}{*}{$\frac{\mathbf{p}}{.00}$} & \multirow{2}{*}{ R } & \multirow{3}{*}{$\begin{array}{c}\mathbf{R}^{\mathbf{2}} \\
.06\end{array}$} \\
\hline & (Değişken) & & & & & & & \\
\hline \multirow[t]{2}{*}{1} & Olumsuz Bilişsel H. & -.04 & .01 & -.24 & -4.57 & .00 & .24 & \\
\hline & (Değişken) & 10.24 & .94 & & 10.88 & .00 & & \\
\hline \multirow{2}{*}{2} & Olumsuz Bilişsel H. & -.04 & .01 & -.21 & -3.97 & .00 & .28 & .08 \\
\hline & DEHB İndeksi & .06 & .02 & .14 & 2.63 & .00 & & \\
\hline
\end{tabular}


İlişkisel saldırganlığı yordayan değişkenleri belirlemek amacıyla yapılan adımsal regresyon analizi Olumsuz Bilişsel Hatalar $(\beta=-.21 ; \mathrm{t}=-$ 3.97; $\mathrm{p}<.01)$ ve $Y C A D O ̈-U F$ 'nin DEHB Índeksi Alt Ölçeği'nin $(\beta=.14 ; \mathrm{t}=$ 2.63; $\mathrm{p}<.01)$ ilişkisel saldırganlığı yordadığını göstermiştir. Olumsuz Bilişsel Hatalar değişkeni tek başına iliş̧isel saldırganlığın \%6'sını $\left(R=24 ; R^{2}=\right.$ .06) yordarken, DEHB İndeksiyle birlikte ilişkisel saldırganlığın \%8'ini açıklamaktadır $\left(\mathrm{R}=28 ; \mathrm{R}^{2}=.08\right)$.

Gözlenen mağduriyeti yordayan değişkenlere yönelik analiz sonuçları Tablo 3'de verilmiştir.

Tablo 3. Gözlenen mağduriyeti yordayan değişkenleri belirlemek üzere yapılan adımsal regresyon analizi'nin sonuçları

\begin{tabular}{|c|c|c|c|c|c|c|c|c|}
\hline \multicolumn{2}{|c|}{ Model } & \multirow{2}{*}{$\frac{\text { B }}{7.65}$} & \multirow{2}{*}{$\frac{\text { SH }}{.22}$} & \multirow[t]{2}{*}{ Beta } & \multirow{2}{*}{$\frac{\mathbf{t}}{34.17}$} & \multirow{2}{*}{$\frac{\mathbf{p}}{.00}$} & \multirow{2}{*}{$\mathbf{R}$} & \multirow{2}{*}{$\mathbf{R}^{\mathbf{2}}$} \\
\hline & (Değişken) & & & & & & & \\
\hline & Kayg1-Utangaçlık & .29 & .06 & .27 & 5.10 & .00 & .21 & \\
\hline & (Değişken) & 11.42 & 1.19 & & 9.62 & .00 & & \\
\hline \multirow{2}{*}{2} & Kayg1-Utangaçlık & .26 & .06 & .23 & 4.44 & .00 & .31 & .10 \\
\hline & Olumsuz Bilişsel H. & -.04 & .01 & -.17 & -3.23 & .00 & & \\
\hline
\end{tabular}

Adımsal regresyon analizi, açıklanan varyansın anlamlı olduğunu göstermektedir $(\mathrm{p}<.01)$. Kaygı-Utangaçlık değişkeni tek başına gözlenen mağduriyetin \%7'sini açıklarken $\left(\mathrm{R}=.27 ; \mathrm{R}^{2}=.07\right)$, Olumsuz Bilişsel Hatalar değişkeni ile birlikte gözlenen mağduriyetin \%10'unu açıklamaktadır $\left(\mathrm{R}=.31 ; \mathrm{R}^{2}=.10\right)$.

İlişkisel mağduriyeti yordayan değişkenlere yönelik analiz sonuçları Tablo 4'de verilmiştir.

Tablo 4. İlişkisel mağduriyeti yordayan değişkenleri belirlemek üzere yapılan adımsal regresyon analizi'nin sonuçları

\begin{tabular}{|c|c|c|c|c|c|c|c|c|}
\hline \multicolumn{2}{|c|}{ Model } & \multirow{2}{*}{$\frac{\text { B }}{13.30}$} & \multirow{2}{*}{$\frac{\text { SH }}{1.12}$} & \multirow[t]{2}{*}{ Beta } & \multirow{2}{*}{$\frac{\mathbf{t}}{11.89}$} & \multirow{2}{*}{$\frac{\mathbf{p}}{.00}$} & \multirow{3}{*}{$\frac{\mathbf{R}}{.26}$} & \multirow{3}{*}{$\begin{array}{l}\mathbf{R}^{\mathbf{2}} \\
.07\end{array}$} \\
\hline & (Değişken) & & & & & & & \\
\hline 1 & Olumsuz Bilişsel H. & -.06 & .01 & -.26 & -4.92 & .00 & & \\
\hline & (Değişken) & 9.61 & 1.6 & & 6.20 & .00 & & \\
\hline \multirow{3}{*}{2} & Olumsuz Bilişsel H. & -.05 & .01 & -.21 & -3.97 & .00 & .31 & .10 \\
\hline & Algılanan Baba T. & .03 & .01 & .18 & 3.39 & .01 & & \\
\hline & (Değişken) & 8.83 & 1.6 & & 5.75 & .00 & & \\
\hline \multirow{3}{*}{3} & Olumsuz Bilişsel H. & -.04 & .01 & -.18 & -3.37 & .00 & & \\
\hline & Algilanan Baba T. & .03 & .01 & .18 & 3.37 & .00 & .33 & .11 \\
\hline & Sosyal Problemler & .22 & .11 & .11 & 2.12 & .03 & & \\
\hline
\end{tabular}


Adımsal regresyon analizi, açıklanan varyansın anlamlı olduğunu göstermektedir $(\mathrm{p}<.05)$. Tablo 4.'de görüldüğü gibi adımsal regresyon analizi (stepwise) sonucu üç farklı model ortaya çıkmıştır. Üçüncü modele göre Olumsuz Bilişsel Hatalar $(\beta=-.18 ; \mathrm{t}=-3.37 ; \mathrm{p}<.01)$, Algılanan Baba Tutumu $(\beta=.18 ; \mathrm{t}=3.37 ; \mathrm{p}<.01)$ ve Sosyal Problemler $(\beta=.11 ; \mathrm{t}=2.12$; $\mathrm{p}<.05)$ değişkenleri ilişkisel mağduriyetin \%11'ini açılamaktadır $(\mathrm{R}=.33$; $\left.\mathrm{R}^{2}=.11\right)$.

\section{TARTIŞMA VE SONUÇ}

Son yıllarda yapılan araştırmalar vurma, itme, küfretme gibi gözlenen saldırgan davranışlara ek olarak dışlama, söylenti yayma, küsme gibi ilişkisel saldırgan davranışların değerlendirilmesinin önemli olabileceğine işaret etmektedir. $\mathrm{Bu}$ araştırmada, gözlenen ve ilişkisel saldırganlık ve mağduriyetle ilgili olduğu düşünülen değişkenler araştırılmıştır. İlk olarak yaş değişkenine bakılmış ve çocuğun yaşı büyüdükçe gözlenen ve ilişkisel saldırganlık düzeyinin azaldığı görülmüştür. İkinci olarak yaş ortak değişken olarak alındığında çocuğun cinsiyetinin, anababanın eğitim düzeyinin ve ailenin gelir grubunun gözlenen ve ilişkisel saldırganlık düzeylerinde anlamlı bir farklılığa kaynaklık etmedikleri görülmüştür. Benzer biçimde söz konusu değişkenlerin gözlenen ve ilişkisel mağduriyet düzeylerinde de anlamlı bir farklılığa kaynaklık etmediği bulunmuştur. Son olarak, gözlenen ve ilişkisel saldırganlık ve mağduriyeti yordayan değişkenler incelenmiştir. $Y C A D O ̈-U F '$ nin DEHB indeksi, karşı gelme ve mükemmeliyetçilik boyutları gözlenen saldırganlığı; olumsuz bilişsel hatalar ve $Y C A D \ddot{O}-U F$ 'nin DEHB

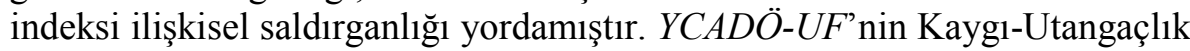
boyutu ve olumsuz bilişsel hatalar gözlenen mağduriyeti; olumsuz bilişsel hatalar, algilanan baba tutumu ve $Y C A D \ddot{O}-U F$ 'nin sosyal problemler boyutunun ise ilişkisel mağduriyeti yordadığı görülmüştür.

Saldırganlık ve mağduriyet alanındaki araştırmalarda belki de en sık çalışılan değişken cinsiyettir. Araştırmalar genelde saldırgan davranışların erkekler arasında yaygın olduğunu gösterse de (Genç ve Aksu, 2010; Joussemet, Vitaro, Barker, Côté, Nagin, Zoccolillo ve Tremblay, 2008; Özkan ve Çifci, 2010; Şahin ve Sarı, 2010) kızların da saldıran davranışlar sergilediği bilinmektedir (Çalık, Özbay, Özer, Kurt ve Kandemir, 2009). Bu araştırmada ise cinsiyete göre gözlenen ve ilişkisel saldırganlık ile mağduriyetin farklılaşmadığı bulunmuştur. Bu bulgu, gözlenen ve ilişkisel mağduriyetin erkekler ve kızlar arasında benzer oranda olduğunu belirten araştırmalarla tutarlıdır (Phelps, 2001; Paquette ve Underwood, 1999). Yurt dışında yapılan bazı araştırmalar gözlenen saldırganlığın erkekler, ilişkisel saldırganlığın kızlar arasında daha yaygın olduğunu (Crick, 1997; Ostrov ve Keating, 2004), kimi araştırmalar ise ilişkisel saldırganlığın erkekler 
arasında daha yaygın olduğunu bulmuştur (Tomada ve Schneider, 1997). Gözlenen ve ilişkisel mağduriyette de erkeklerin gözlenen saldırganlığa maruz kaldıkları, kızların ise daha çok ilişkisel saldırganlığa maruz kaldıklarını göstermiştir (Crick ve Bigbee, 1998; Crick ve Grotpeter, 1996). $\mathrm{Bu}$ çalışmada ise saldırganlıkta olduğu gibi mağduriyette de cinsiyete göre bir farklılaşmanın olmadığ 1 bulunmuştur. Kız ve erkek çocukların benzer düzeyde saldırgan davranış sergılemeleri ve benzer düzeyde bunlara maruz kalmaları yönünde elde edilen bulguların izleyen diğer çalışmalarla da desteklenmesi gerektiğini belirtmekle birlikte, varolan bulgular 1şı̆ğında hem kızların hem de erkeklerin benzer düzeyde risk altında oldukları söylenebilir.

Akran saldırganlığ 1 ve mağduriyetinin yaşla birlikte nasıl değiştiğini inceleyen araştırmalar, gözlenen saldırganlığın ve gözlenen mağduriyetin yaşla birlikte azaldığını, ilişkisel saldırganlığın ve ilişkisel mağduriyetin ise yaşla birlikte arttığını göstermiştir (Loeber ve Hay, 1997). Ancak bu araştırmada, çocuğun yaşı büyüdükçe hem gözlenen saldırganlığın hem de ilişkisel saldırganlığın azaldığı bulunmuştur. Başka bir çalışmada da Lee, Baillargeon, Vermunt, Wu ve Tremblay (2006) kız çocuklarında, yaşla birlikte gözlenen saldırgan davranışların azaldığını bulmuştur. Türkiye'de yapılan bir çalışmada ise yaşla birlikte sözel zorbalık ve sözel mağduriyetin arttığı belirtilmiştir (Genç ve Aksu, 2010). Bu çalışmada ilişkisel ve gözlenen saldırganlığın yaşla birlikte azaldığı bulunmuştur. Çocukların yaşı büyüdükçe gözlenen saldırgan davranışların azalması çocukların bilişsel ve sosyal gelişimlerine bağlı olabileceği gibi okul yönetimlerinin daha büyük yaştaki çocukların saldırgan davranışlarına daha az tolerans göstermelerinden kaynaklanabilir.

Çocuğun saldırgan davranışlarının gelişiminde bilişsel süreçlere vurgu yapan araştırmacılar, akran saldırganlığı ve mağduriyetine ilişkin çeşitli bilişleri incelemişlerdir. Örneğin, saldırganlığın sonuçlarına ilişkin olumlu beklentilere sahip olma (Lochman ve Dodge, 1994), kışkırtma içeren ya da çelişkili durumlarda sosyal ipuçlarını düşmanca algılama (Crick ve Dodge, 1996), sosyal bağlamlarda daha düşmanca amaçlar edinme (Erdley ve Asher, 1996), saldırgan davranışların kabul edilebilir olduğunu düşünme (Huesmann ve Guerra, 1997), saldırganlığın kolay olduğunu düşünme (Camodeca ve Goossens, 2004), saldırgan fanteziler kurma (Huesmann, 1988), az sayıda alternatif problem çözme stratejisi üretme (Asarnow ve Callon, 1985), saldırganlığa ilişkin normatif inançlara sahip olma (Huesmann ve Guerra, 1997), saldırgan tepkilere yönelik bilgilere kolayca erişebilme, düşmanca yüklemede bulunma gibi bilgi işleme sürecinin çeşitli özellikleri (Fontaine, Yang, Dodge, Bates ve Pettit, 2008) ve bilişsel çarpıtmalar (Epkins, 2000; Leung ve Poon, 2001) ile saldırganlık arasında ilişsi olduğu görülmüştür. Bu araştırmanın bulguları da varolan alanyazın ile tutarlı olarak olumsuz bilişsel hataların ilişkisel saldırganlık, ilişkisel 
mağduriyet ve gözlenen mağduriyetin en güçlü yordayıcılarından biri olduğunu göstermiştir. $\mathrm{Bu}$ araştırma kapsamında değerlendirilen olumsuz bilişsel hatalar ise gözlenen saldırganlığı yordamamıştır. Belki de, gözlenen saldırganlık doğrudan çocuğun bu davranışıyla ilgili olumsuz bilişsel hatalarla ilgili ve duruma özgü olabilir. Gözlenen saldırgan davranışları gösteren çocuklarla yapılacak daha ayrıntılı çalışmalar bu çocuklara ve duruma özgü olumsuz bilişsel hataların olup olmadığı konusunu açıklığa kavuşturabilir.

Araştırmanın bulguları, saldırganlık ve mağduriyetin duygusal davranışsal problemlerle de ilişkili olduğunu göstermiştir. Adımsal regresyon analizlerinin sonucunda, Dikkkat Eksikliği Hiperaktivite ile birlikte Olumsuz Bilişsel Hatalar ilişkisel saldırganlığı yordamıştır. Dikkat Eksikliği Hiperaktivitenin Karşı Gelme ve Mükemmeliyetçilik ile birlikte gözlenen saldırganlığ 1 da yordadığ 1 görülmüştür. Olumsuz Bilişsel Hatalar da Kaygı-Utangaçlık ile birlikte gözlenen mağduriyeti yordamıştır. İlişkisel mağduriyeti ise, Olumsuz Bilişsel Hatalar, Algılanan Baba Tutumu ve Sosyal Problemler yordamıştır. Yukarıda özetlenen bu bulguların alanyazındaki araştırma bulgularıyla genel olarak tutarlı olduğu görülmüştür. Örneğin Türkiye'de ergenlerle yapılan bir çalışmada da hem olumlu hem de olumsuz mükemmeliyetçiliğin saldırganlığı yordadığı bulunmuştur(Öngen, 2009). Abikoff v.d.'nin (2002) yaptıkları bir çalışmada, DEHB tanısı alan kız çocuklarının sıklıkla sözel saldırgan davranışlar sergilediklerini, erkek çocukların ise kurallara karşı geldiklerini ve genel olarak dışayönelim sorunları sergilediklerini bulmuştur.

Araştırmalar gözlenen mağduriyetin sosyal kaçınma (Storch ve MasiaWarner, 2004) ve depresyon (Storch, Zelman, Sweeny, Danner ve Dove, 2002) ile ilişkili olduğunu, ilişkisel mağduriyetin ise sosyal kaygı (Storch, Masia-Warner, Crisp ve Klein, 2005) ile ilişkili olduğunu göstermiştir. Benzer biçimde, bu araştırmada da gözlenen mağduriyetin yordayıcılarından birinin Kaygı-Utangaçlık olduğu, ilişkisel mağduriyetin yordayıcılarından birinin de Sosyal Problemler olduğu görülmüştür. Ülkemizde zorbalık konusunda yapılan bir çalışmanın sonuçları da bu bulguları destekler niteliktedir. Yıldırım, Tezer ve Çileli (2005), zorba ve zorba/mağdur gruplarında yer alan çocukların akranları tarafından sıklıkla yıkıcı ve kavgacı olarak değerlendirildiğini, mağdurların ise utangaç olarak değerlendirildiğini bulmuștur.

$\mathrm{Bu}$ araştırmada, algılanan olumsuz baba tutumunun ilişkisel mağduriyeti yordadığı bulunmuştur. Alanyazında özellikle algılanan baba davranışı ya da tutumuna yönelik çok fazla araştırma bulunmamakla birlikte, otoriter ve ilgisiz anababa algısının suç işleme davranışıyla ilişkili olduğu gösterilmiştir (Balkaya ve Ceyhan, 2007). Bu bulgu, babanın çocuğa gösterdiği duygusal yakınlık ve baba-çocuk arasındaki ilişkinin kalitesinin 
çocuğun arkadaşlık ilişkileriyle bir şekilde bağlantılı olabileceğine işaret etmektedir. Bununla birlikte izleyen araştırmalarla, baba-çocuk ilişkisinin çocuğun arkadaşlık ilişkilerine nasıl ve ne derecede etkilediği daha ayrıntılı biçimde çalışılmalıdır.

$\mathrm{Bu}$ araştırmanın bazı sınırlılıkları bulunmaktadır. Örneğin, yalnızca 6-8 sınıfa devam eden ilköğretim öğrencileri bu çalışmaya katılmıştır. Halbuki, saldırganlık ve mağduriyetin okul-öncesi dönemden (Erdinç, 2009) başladığ 1 bilinmektedir. Araştırmanın bir başka sınırlılı̆̆ değişkenini belirlemenin güçlügü ile ilgilidir. Bu nedenle, çalışmada farklı SED'den olduğu düşünülen okullar seçilmiş ve anababanın eğitim düzeyi ile ailenin gelir düzeyi değerlendirilmiştir. Araştırmada yalnızca öz-bildirim araçlarından yararlanılması da bir başka sınırlılıktır. Gözlem teknikleri ve öğretmen görüşlerinin de alınması, saldırganlık ve mağduriyete yönelik daha kapsamlı bilgiler verebilir. Bununla birlikte, saldırganlık ve mağduriyet kapsamında yapılacak gelecekteki araştırmalar, bu araştırmanın sınırlılıklarını da dikkate alarak aşağıda belirtilen hususları aydınlatmaya çalışabilir.

İlk olarak, araştırmalar, saldırgan davranışlar gösteren çocukların veya bu davranışlara maruz kalan çocukların, karşılaştıkları sorunlarla nasıl baş ettiklerini değerlendirmelidir. Böylece her iki grupta yer alan çocukların kullandıkları sağlıklı ve sağlıksız (işlevsel/yapıcı ve işlevsiz/uyum bozucu) başetme stilleri ile sorun alanları arasındaki ilişkiler ortaya çıkarılabilir. Örneğin, mağduriyetin kronik hale gelmesine neden olan başetme stilleri belirlenebilir.

İkinci olarak, sosyal bilgi işleme kuramı, çocukların saldırgan davranışlarının gelişimine ilişkin önemli bilgiler sunmuştur (Bandura v.d. 1996; Crick ve Dodge, 1996). Sosyal bilgi işleme kuramı çerçevesinde, mağduriyetin sistematik bir biçimde çalışılması mağdurlara ilişkin önemli bilgiler sunabilir. Ayrıca, bu araştırmanın bulguları olumsuz bilişsel hataların ilişkisel ve gözlenen mağduriyeti yordadığını göstermiştir. Olumsuz bilişsel hataların bu denli önemli bulunması, hem pratikte eğitimciler, (örneğin, çocuklara gerçekçi düşünme becerilerini öğretme gibi) hem de araştırmacılar (örneğin önleme programlarına gerçekçi düşünme becerilerinin eklenmesi gibi) için "gerçekçi düşünme" becerisinin geliştirilmesi konusunun ne kadar önemli olabileceğine işaret etmektedir.

Üçüncü olarak, bu çalışmada olduğu gibi pek çok çalışmada saldırganlık ve mağduriyet ile çeşitli uyum sorunları arasında ilişki olduğu bulunmuştur. Ancak saldırganlık ve mağduriyet ile uyum sorunları arasındaki neden-sonuç ilişkileri henüz açıklanabilmiş değildir. Üstelik saldırganlığın gözlenen ve ilişkisel biçimleri ile mağduriyetin gözlenen ve ilişkisel biçimleri farklı gelişimsel aşamalardan geçiyor olabilir. Bu nedenle, özellikle boylamsal çalışmalarla, saldırganlık ve mağduriyetinin farklı 
biçimlerinin yaşa veya gelişimsel dönemlere bağlı olarak nasıl geliştiği incelenebilir.

Son olarak, akran ilişkilerinin antisosyal davranışların geliştirilmesine ve sürdürülmesine olan katkısı alanyazında mevcuttur (Hymel, Wagner ve Butler, 1990). Ancak olumsuz akran ilişkilerinin yanı sıra olumlu akran ilişkilerinden mahrum kalmak da saldırganlık ve mağduriyet ile ilişkili olabilir. Örneğin, akran reddinin saldırganlığı yordadığı bulunmuştur (Laird v.d. 2001). Bu nedenle, gelecekte yapılacak olan araştırmalar, olumlu akran ilişkilerinden mahrum kalma ile saldırganlık ve mağduriyet arasındaki ilişkileri çalışabilir. Ayrıca, olumlu akran ilişkilerinin ve bu ilişkilerden mahrum kalmanın, saldırganlık ve mağduriyetin çocuk üzerinde yarattı̆̆ 1 olumsuz etkilerin düzeyinde farklılık yaratıp yaratmadığı da çalışılabilir.

$\mathrm{Bu}$ araştırma, hem Türkiye'de hem de yurt dışında, saldırganlık ve mağduriyet kapsamında daha önce değerlendirilmemiş bazı değişkenleri ele alması ve uygulamaya yönelik olası katkıları açısından önemlidir. $\mathrm{Bu}$ araştırma sonucunda, çocuğun yaşı büyüdükçe gözlenen ve ilişkisel saldırganlık düzeyinin azaldığı görülmüsstür. $\mathrm{Bu}$ bulgudan hareketle eğitimcilerin ve okul psikolojik danışmanlarının alt sınıf öğrencileriyle saldırgan davranışların azaltılması konusuna daha fazla yoğunlaşmaları gerekebilir. Ayrıca, dikkat eksikliği ve hiperaktivite belirtileri ile karşı gelme ve mükemmeliyetçilik belirtilerinin saldırgan davranışını sergileme açısından risk olarak belirmiştir. Benzer biçimde, kaygi-utangaçlık, olumsuz bilişsel hatalar ve sosyal problemler ise gözlenen ve ilişkisel mağduriyet açısından risk etmeni olduğu görülmüştür. Okul psikolojik danışmanlarının bu belirtileri gösteren çocuklarla bireysel olarak ilgilenmeleri uygun olacaktır. Örneğin saldırganlık ve/veya karşı gelme sorunları yaşayan çocuğa öfke kontrol eğitimi, mağduriyet ve/veya kaygı-utangaçlık sorunları yaşayan çocuğa atılganlık eğitimi verilebilir. Bu belirtilerin devam etmesi durumunda ise daha kapsamlı bir destek için çocuğun bir klinisyene yönlendirilmesi uygun olacaktır. 


\section{KAYNAKLAR}

Abikoff, H.B., Jensen, P.S., Arnold, L.L. E.A., Hoza, B., Hechtman, L., Pollack, S., Martin, D., Alvir, J., March, J. S., Hinshaw, S. et al. (2002). Observed classroom behavior of children with ADHD: relationship to gender and comorbidity. Journal of Abnormal Child Psychology, 30 (4), 349-59.

Alink, L., Mesman, J., van Zeijl, J., Stolk, M., Juffer, F., Bakermans-Kranenburg, M., et al. (2009). Maternal sensitivity moderates the relation between negative discipline and aggression in early childhood. Social Development, 18(1), 99120.

Archer, J. (2004). Sex differences in aggression in real-world settings: a metaanalytic review. Review of General Psychology, 8, 291-322.

Arrindell, W. A., Sanavio, E., Aguilar, G., Sica, C., Hatzichristou, C., Eisemann, M., Recinos, L. A., Gazsner, P., Meter, M.,Battagliese, J., Kállai, J. \& Van der Ende, J. (1999). The development of a short form of the EMBU: Its appraisal with students in Greece, Guatemala, Hungary and Italy. Personality and Individual Differences, 27, 613-628.

Asarnow, J. R., Callon, J. W. (1985). Boys with peer adjustment problems: social cognitive processes. Journal of Consulting and Clinical Psychology, 53, 80-87.

Balkaya, A. ve Ceyhan, E. (2007), Lise Öğrencilerinin Suç Davranışı Düzeylerinin Bazı Kişisel ve Ailesel Nitelikler Bakımından İncelenmesi. Aile ve Toplum Dergisi, 3, 11, 13-27.

Bandura, A., Barbaranelli, C., Caprara, G. V., Pastorelli, C. (1996). Mechanisms of moral disengagement in the exercise of moral agency. Journal of Personality and Social Psychology, 71, 364-374.

Bayer, C. L., Cegala, D. J. (1992). Trait verbal aggressiveness and argumentativeness: relations with parenting style. Western Journal of Communication, 56, $301-310$.

Burnette, M., \& Reppucci, N. (2009). Childhood abuse and aggression in girls: the contribution of borderline personality disorder. Development and Psychopathology, 21(1), 309-317.

Camodeca, M., Goossens, F.A. (2004). Aggression, social cognitions, anger and sadness in bullies and victims. Journal of Child Psychology and Psychiatry, 46(2), 186-197.

Cheng, C.L. (2009). No blood means less harm?: relational aggression and peer rejection in adolescence. Bulletin of Educational Psychology, 40 (3), 511-528.

Cicchetti, D., Ackerman, B. P., Izard, C. E. (1995). Emotions and emotion regulation in developmental psychopathology [Special Issue]. Development and Psychopathology, 7, 1-10.

Cillessen, A. H. N., Mayeux, L. (2004). From censure to reinforcement: developmental changes in the association between aggression and social status. Child Development, 75, 147-163.

Coie, J. D., Lochman, J. E., Terry, R. \& Hyman, C. (1992). Predicting early adolescent disorder from childhood aggression and peer rejection. Journal of Consulting and Clinical Psychology, 60 (5), 783-792. 
Crick, N. (1997). Engagement in gender normative versus nonnormative forms of aggression: links to social-psychological adjustment. Developmental Psychology, 33, 610-617.

Crick, N. C., Dodge, K. A. (1996). Social information processing deficits in reactive and proactive aggression. Child Development, 67, 993-1002.

Crick, N. R. \& Bigbee, M. A. (1998). Relational and overt forms of peer victimization: a multi-1nformant approach. Journal of Consulting and Clinical Psychology, 66, 337-347.

Crick, N. R. \& Grotpeter, J. (1995). Relational aggression, gender, and socialpsychological adjustment. Child Development, 66, 710-722.

Crick, N. R. \& Grotpeter, J. K. (1996). Children's treatment by peers: victims of relational and overt aggression. Development and Psychopathology, 8, 367380 .

Crick, N. R. (1996). The role of overt aggression, relational aggression, and prosocial behavior in the prediction of children's future social adjustment. Child Development, 67, 2317-2327.

Crick, N. R., Werner, N. E. (1998). Response Decision Processes in Relational and Overt Aggression. Child Development, 69, 1630-1639. 859.

Çalık, T., Özbay, Y., Özer, A., Kurt, T., ve Kandemir, M. (2009). İlköğretim Okulu Öğrencilerinin Zorbalık Statülerinin Okul İklimi, Prososyal Davranıșlar, Temel İhtiyaçlar ve Cinsiyet Değiş̧kenlerine Göre İncelenmesi. Kuram ve Uygulamada Eğitim Yönetimi, 15 (60), 555-576.

Dodge, K. A., Coie, J. D. (1987). Social-information-processing factors in reactive and proactive aggression in children's peer groups. Journal of Personality and Social Psychology, 53, 1146-1158.

Dodge, K. A., Schlundt, D. C., Schocken, I., Delugach, J. D. (1983). Social Competence and Children's Sociometric Status: the Role of Peer Group Entry Strategies. Merrill-Palmer Quarterly, 29 (3), 309-336.

Dölek, N. (2002). İlk ve Ortä̈ğretim Okullarındaki Öğrenciler Arasında Zorbaca Davranışların Incelenmesi ve Zorbalığı Önleme Tutumu Geliştirmek Iç̧in Hazırlanan Bir Programın Etkisinin Araştırılması. Yayınlanmamış Doktora Tezi, Marmara Üniversitesi,Sosyal Bilimler Enstitüsü, İstanbul.

Eisenberg, N., Fabes, R. A., Guthrie, I. K., Murphy, B. C., Maszk, P., Holmgren, R., Suh, K. (1996). the Relations of Regulation and Emotionality to Problem Behavior in Elementary School Children. Development and Psychopathology, $8,141-162$.

Epkins, C. C. (2000). Cognitive specificity in internalizing and externalizing problems in community and clinic-referred children. Journal of Clinical Child Psychology, 29, 199-208.

Erdley, C., A.Asher, S. R. (1996). Children's social goals and self-efficacy perceptions as influences on their responses to ambiguous provocation. Child Development, 67, 1329-1344.

Fontaine, R. G., Yang, C., Dodge, K. A., Bates, J. E., Pettit, G. S. (2008). Testing an individual systems model of response evaluation and decision (RED) and antisocial behavior across adolescence. Child Development, 79, 462-475.

Genç, G. ve Aksu, M.B. (2010). Genel lise öğrencilerinin zorba-kurban davranışlarının çeşitli değişkenler açısından incelenmesi. GÜ, Gazi Ĕ̈itim Fakültesi Dergisi, 30 (2), 413-448. 
Giles J. W., Heyman G. D. (2005). Preschoolers Use Trait - Relevant Information to Evaluate the Appropriateness of an Aggressive Response. Aggressive Behaviour, 31, 498-509.

Hill, A., Degnan, K., Calkins, S.D. \& Keane, S.P. (2006). Profiles of externalizing behavior problems for boys and girls across preschool: The roles of emotion regulation and inattention. Developmental Psychology, 42, 913-928.

Huesmann, L. R. Guerra, N. G. (1997). Normative beliefs and the development of aggressive behavior. Journal of Personality and Social Psychology, 72(2), 112.

Huesmann, L.R. (1988). An information processing model for the development of aggression. Aggressive Behavior, 14, 13-24.

Hymel, S., Wagner, E. \& Butler, L.J. (1990). Reputational bias: View from the peer group. In S.R. Asher \& J.D. Coie (Eds.), Peer Rejection in Childhood, (pp. 156- 188). New York:Cambridge University Press.

Joussemet, M., Vitaro, F., Barker, E. D., Côté, S., Nagin, D. S., Zoccolillo, M., \& Tremblay, R. E. (2008). Controlling parenting and physical aggression during elementary school. Child Development, 79, 411-425.

Kaner, S., Büyüköztürk, Ş., İşeri E., Ak A., Özaydın, L. (2006, Nisan). Yenilenmiş Conners Anababa Dereceleme Ölçeği-Uzun Formunun Türkçe Uyarlama Çalışması. 16. Ulusal Çocuk ve Ergen Ruh Sağlığı ve Hastalıkları Kongresi, Antalya.

Kapçı, E. G. ve Kurnaz, A. (2009, Ekim). Illköğretim 6-8. Sinıf Öğrencilerinde İlişkisel ve Gözlenen Saldırganlı̆̆ın Değerlendirilmesine İlişkin Bir Ölçek Uyarlama Çalışması. X. Ulusal Psikolojik Danışma ve Rehberlik Kongresi'nde sunulmuş bildiri, Adana.

Kapçı, E.G., Uslu, R.I., Akgün, E ve Acer, D. (2009). İlköğretim çağı çocuklarında duygu ayarlama: Bir ölçek uyarlama çalışması ve duygu ayarlamayla ilişkili etmenlerin belirlenmesi. Çocuk ve Gençlik Ruh Sağlı̆̆ Dergisi, 16, 13-20.

Kovacs, M.(1992). Children's Depression Inventory (CDI): Manual. Toronto: MultiHealth Systems Inc.

Kurnaz, A. ve Kapçı, E. G. (2009, Ekim). Gözlenen ve İlişkisel Mă̆duriyetin Değerlendirilmesine Illişkin Bir Ölçek Uyarlama Çalışması. X. Ulusal Psikolojik Danışma ve Rehberlik Kongresi'nde sunulmuş bildiri, Adana.

Laird, R. D., Jordan, K. Y., Dodge, K. A., Pettit, G. S. , Bates, J. E. (2001). Peer Rejection in Childhood, Involvement With Antisocial Peers in Early Adolescence, and the Development of Externalizing Behavior Problems. Development and Psychopathology, 13, 337-354.

Lee, K., Baillargeon, R.H., Vermunt, J.K., Wu, H., \& Tremblay, R.E. (2006). Age differences in the prevalence of physical aggression among 5-11-year old Canadian boys and girls, Aggressive Behavior, 33, 26-37.

Leitenberg H, Yost LW, Carroll-Wilson M ve ark. (1986) Negative cognitive errors in children: questionnaire development, normative data, and comparison between child with and without self-reported symptoms of depression, low self-esteem, and evaluaton anxiety. Journal of Consulting and Clinical Psychology, 54, 528-536.

Leitenberg, H., Yost L.W., Caroll-Wilson, M. (1986). Negative Cognitive Errors in Children: Questionnaire Development, Normative Data, and Comparisons Between With and Without Self-Reported Symptoms of Depression, Low Self- 
Esteem, and Evaluation Anxiety. Journal of Consulting and Clinical Psychology, 54 (4), 528-536.

Leung, P. W. L., Poon, M.W. L. (2001). Dysfunctional schemas and cognitive distortions in psychopathology: A test of the specificity hypothesis. Journal of Child Psychology and Psychiatry, 42, 755-765.

Levenson, R.W. (1994). Human emotion: A functional view. In P. Ekman \& R. Davidson (Eds.). The Nature of Emotion: Fundamental Questions (s. 123-126). New York: Oxford University Press.

Lochman, J. E., Dodge, K. A. (1994). Social-cognitive processes of severely violent, moderately aggressive, and nonaggressive boys. Journal of Consulting and Clinical Psychology, 62, 366-374.

Loeber, R., Hay, D. (1997) Key Issues in the Development of Aggression and Violence From Childhood to Early Adulthood. Annual Review of Psychology, 48, 371-410.

Matsumoto, D. (2002). Methodological requirements to test a possible ingroup advantage in judging emotions across cultures: Comments on Elfenbein and Ambady and evidence. Psychological Bulletin, 128, 236-242,

Olweus, D. (1996). Bully/victim problems at school: facts and effective intervention. Reclaiming Children and Youth, 5 (1), 15-22.

Ostrov, J. M., Crick, N. R. (2007). Forms and Functions of Aggression During Early Childhood: A Shortterm Longitudinal Study. School Psychology Review, 36, 22-43.

Ostrov, J. M., Keating C. F. (2004). Gender Differences in Preschool Aggression During Free Play and Structured Interactions: an Observational Study. Social Development, 13, 255-277.

Ostrov, J. M., Woods, K. E., Jansen, E. A., Casas, J. F., Crick, N. R. (2004). An observational study of delivered and received aggression and social psychological adjustment in preschool: "this white crayon doesn't work." Early Childhood Research Quarterly, 19, 355- 371.

Öngen, D. E. (2009). The relationship between perfectionism and aggression among adolescents. Procedia Social and Behavioral Sciences, 1, 1073-1077.

Özkan, Y. ve Çifci, E.G. (2010). Düşük Sosyo-Ekonomik Düzeydeki İlköğretim Okullarında Akran Zorbalığı. İlköğretim Online, 9 (2), 576-586. [Online]: http://www.akademikbakis.org adresinden 27.07.2011 tarihinde alınmıştır.

Paquette, J. A., Underwood, M. K. (1999). Gender Differences in Young Adolescents' Experiences of Peer Victimization: Social and Physical Aggression. Merrill-Palmer Quarterly, 45, 242-266.

Perris, C., Jacobsson, L., Lindström, H., Von Knorring, L. \& Perris, H.(1980). Development of a new inventory for assessing memories of parental rearing behaviour. Acta Psychiatrica Scandinavica, 61, 265-274.

Phelps, C.E.R. (2001). Children's response to overt and relational aggression. Journal of Clinical Child Psychology, 30(1), 240-252.

Phelps, E. A. (2006). Emotion and cognition: insights from studies of the human amygdala. Annual Review of Psychology, 57, 27-53.

Rudolph KD. V \& Clark AG. (2001), Conceptions of relationships in children with depressive and aggressive symptoms: Social-cognitive distortion or reality?, Journal of Abnormal Child Psychology, 29(1), 41-56. 
Rydell, A. M., Berlin, L., Bohlin, G. (2003). Emotionality, Emotion Regulation, and Adaptation among 5- to 8-Year-Old Children. Emotion, 3, 30-47.

Sandstrom, M.J. (2007). A link between mothers' disciplinary strategies and children's relational aggression. British Journal of Developmental Psychology, $25,399-407$.

Schwartz, D., Gorman, A.H., Dodge, K.A., Pettit, G.S., \& Bates, J.E.(2008). Friendships with peers who are low or high in aggression as moderators of the link between peer victimization and declines in academic functioning. Journal of Abnormal Child Psychology, 36, 719-730.

Shields, A., Cicchetti, D. (1997). Emotion Regulation among School-Age Children: the Development and Validation of A New Criterion Q-Sort Scale. Developmental Psychology, 33, 906-916.

Shields, A., Cicchetti, D. (1998). Reactive Aggression among Maltreated Children: the Contributions of Attention and Emotion Dysregulation. Journal of Clinical Child and Adolescent Psychology, 27, $381-395$.

Storch, E. A., Masia-Warner, C. (2004). The relationship of peer victimization to social anxiety and loneliness in adolescent females. Journal of Adolescence, 27, 351-362.

Storch, E. A., Phil, M., Nock, M. K., Masia-Warner, C., Barlos, M. E. (2003) Peer Victimization and social-psychological adjustment in Hispanic and AfricanAmerican Children. Journal of Child and Family Studies, 12(4), 439-452.

Storch, E., Zelman, E., Sweeny, M., Danner,G., \& Dove, S. (2002). Overt and relational victimization and psychosocial adjustment in minority preadolescents. Child Study Journal, 32, 73-80.

Storch, E.A., Masia-Warner, C., Crisp, H. \& Klein, R.G. (2005). Peer victimization and social anxiety in adolescence: a prospective study. Aggressive Behavior, $31,437-452$.

Storch, E.A., Masia-Warner, C., Crisp, H., Klein, R.G. (2005). Peer Victimization and Social Anxiety in Adolescence: A Prospective Study. Aggressive Behavior, $31,437-452$.

Sümer, N., ve Engin, E. (2004, Temmuz). Role of parenting styles in predicting attachment anxiety and avoidance. Paper presented at the International Association for Relationship research Conference, Madison.

Şahin, M. ve Sarı, S. V. (2010). Ergenlerde Görülen Zorbalık Eğiliminin Bilişsel Çarpitmalar ve Fonksiyonel Olmayan Tutumlarla İlişkisi. Akademik Bakış Dergisi, 20, 1-14.

Tomada, G., \& Schneider, B. H. (1997). Relational aggression, gender, and peer acceptance: Invariance across culture, stability over time, and concordance among informants. Developmental Psychology, 33, 601-609.

Werner N, Crick N. (1999). Relational aggression and social-psychological adjustment in a college sample. Journal of Abnormal Psychology, 108, 615623.

Yıldırım, S., Tezer, E., Çileli, M. (2005). Bir Ilköğretim Okulundaki Zorba, Kurban, Zorba/Kurban ve Kontrol Gruplarının Davranış Özellikleri ve Hoşlanılma Düzeyleri. Eğitim ve Bilim, 30(136), 84-90. 